\title{
Sistem Informasi Antrean Pada Pusat Layanan Kesehatan Masyarakat Dengan Electronik Kartu Tanda Penduduk Menggunakan Radio Frequency Identification
}

\section{Information System At Public Health Service Centers With Electronic Identity Cards Using Radio Frequency Identification}

\author{
Riky Adbul Gani Anwar ${ }^{1 *}$, Kartarina ${ }^{2}$, Miftahul Madani ${ }^{3}$ \\ 1,2,3 Universitas Bumigora \\ rickyanwar777@gmail.com ${ }^{1 *}$, kartarina@universitasbumigora.ac.id², madani@universitasbumigora.ac.id ${ }^{3}$
}

\begin{abstract}
Abstrak - Guna mendapatkan pelayanan Kesehatan di Pusat Pelayanan Kesehatan Masyarakat (Puskesmas) biasanya diawali dengan antrean. Pasien akan mendaftar terlebih dahulu ke loket dan kemudian diberikan nomor antrian manual dan petugas mencatat kedalam buku kunjungan dan buku tersebut sebagai rekam kunjungan sehingga setiap kali kunjungan, staf akan mencari buku pasien dan memastikan apakah pasien terdaftar atau tidak, yang menyebabkan proses pelayanan menghabiskan waktu lebih banyak. Dari permasalahan tersebut maka dilakukan penelitian untuk sistem antrean dengan memanfaatkan teknologi IoT (Internet of Things) yaitu RFID (Radio Frequency Identification) dengan obkjek e-KTP (electronic Kartu Tanda Penduduk). Pada penelitian dengan menggunakan e-KTP yang di tempelkan pada alat RFID perekaman informasi pengunjung puskesmas cukup satu kali pendataan saja dan untuk kunjungan berikutnya pengunjung tidak perlu dicatat lagi identitasnya, pengunjung puskesmas hanya mendaftar ke bagian/ poli yang ingin didatangi, seingga dapat memudahkan petugas / staf Puskesmas. Penelitian ini menggunakan metode Guidelines for Rapid Application Engineering (GRAPPLE) agar dapat menghasilkan luaran dari sistem ringkas namun tidak mengurangi kualitas sistem yang dibangun. Penelitian ini bertujuan untuk memudahkan pelayanan Puskesmas salah satunya pada proses antrean. Presentase kelayakan sistem tersebut yaitu $83 \%$.
\end{abstract}

Kata Kunci: Sistem Informasi, Internet of Things, Mikrokontroler, e-KTP, RFID

\begin{abstract}
In order to get health services at the Community Health Service Center (Puskesmas) usually begins with a queue. Patients will register first at the counter and then be given a manual queue number and the officer records it into the visit book and the book as a visit record so that every time the visit, the staff will look for the patient book and confirm whether the patient is registered or not, which This causes the service process to take more time. From these problems, research was carried out for the queuing system, queuing by utilizing IoT (Internet of Things) technology, namely RFID (Radio Frequency Identification) with e-KTP (electronic Identity Card) objects. In research using e-KTP which is attached to an RFID device, recording information on puskesmas visitors is enough to collect data only once and for the next visit, visitors do not need to record their identity again, public health center visitors only register to the section/poly they want to visit, so it can make it easier for officers / health center staff. This study uses the Guidelines for Rapid Application Engineering (GRAPPLE) method in order to produce output from a concise system but does not reduce the quality of the system built. This study aims to facilitate public health center services, one of which is the queuing process. The percentage of the feasibility of the system is $83 \%$.
\end{abstract}

Keywords: Information System, Internet of Things, Mikrokontroler, e-KTP, RFID.

Jurnal Bumigora Information Technology (BITe)

Vol.3, No.1, Juni 2021, pp. 9-18

ISSN: $2685-4066$

DOI: $10.30812 /$ bite.v3i1.1304 


\section{Pendahuluan}

Seiring dengan pertambahan penduduk yang semakin pesat di Indonesia sekarang ini mengharuskan kita semua untuk membudayakan budaya antre, terutama tempat padat akan aktivitas masyarakat. Antrean merupakan aktivitas menunggu untuk dilayani oleh satu orang atau lebih guna mendapatkan pelayanan yang diinginkan, Antrean adalah orang-orang atau barang dalam sebuah barisan yang sedang menunggu untuk dilayani[1]. Fenomena ini terjadi karena adanya ke tidak keimbangan antara yang dilayani dan pelayanannya maka akan terjadi antrean dalam waktu panjang, sehingga menimbulkan kerugian pada badan usaha atau lembaga tersebut [2]. Pada dasarnya pekerjaan mengantre merupakan hal yang tidak disenangi hampir setiap orang, dalam hal ini setiap orang pasti ingin mendapatkan pelayanan yang terbaik.

Untuk mendapatkan pelayanan kesehatan sangat susah di tentukan jumlah trafik karena kita tidak tahu kapan orang sakit atau membutuhkan layanan kesehatan [3]. Hal ini tentu sangat mempengaruhi lamanya antrean pada pelayanan kesehatan. Dalam kunjungan ke pelayanan kesehatan pengunjung biasanya akan di berikan kartu berobat, kartu berobat tersebut berupa kertas dengan identitas pasien, sering kali kartu tersebut rusak atau pasien tidak membawa kartu tersebut. Sehingga setiap kali kunjungan, staf akan memastikan apakah pasien terdaftar atau tidak, yang menyebabkan proses pelayanan menghabiskan waktu lebih banyak.

Teknologi RFID (Radio Frequency Identification) merupakan teknologi yang dapat melakukan many-to-many communication artinya banyak reader dapat membaca satu tag, maupun satu reader dapat membaca banyak tag [4][5]. Sistem RFID merupakan sistem yang digunakan untuk mengirimkan data dari Piranti portabel yang disebut tag dan dibaca oleh RFID reader, kemudian dilakukan pemrosesan oleh komputer yang telah disiapkan database. Sebagai RFID tag dikarenakan dalamnya terdapat sebuah chip yang menyimpan kode unik. Data yang dipancarkan dan dikirimkan dapat berisi beragam informasi [4][6].

Dari permasalahan tersebut, peneliti membuat sistem antrean tunggu dengan memanfaatkan teknologi RFID dengan menggunakan Elektronik Kartu Tanda Penduduk (E-KTP). Terminal Reader RFID digunakan pembaca atau pengubah informasi yang tersimpan dalam tag melalui frekuensi radio.Terminal RFID terhubung langsung dengan sistem host komputer [7]. Sistem informasi ini memanfaatkan kode unik tersebut sebagai identitas pasien jadi cukup dengan memindai e-KTP maka secara langsung memberikan informasi pasien sehingga petugas tidak perlu memastikan kembali status pasien setiap kali kunjungan.

\section{Metode Penelitian}

Metodologi penelitian dan pengembangan perangkat lunak (software) yang digunakan adalah Metode Guidelines for Rapid Application Engineering (GRAPPLE). yang bertujuan untuk menghasilkan sistem berorientasi objek dalam waktu yang singkat tanpa mengurangi kualitas sistem yang dibangun [8]. Metode ini merupakan pemodelan proses pengembangan perangkat lunak dengan menitik beratkan pada aksi-aksi yang dilakukan pada sejumlah tahapan, dimana setiap tahapan akan menghasilkan output dengan bentuk yang berorientasi object. metode ini terdiri dari 5 bagian yaitu, Requirement Gathering, analysis, design, deployment. Requirement merupakan tahap pengumpulan informasi apa saja yang di butuhkan dalam pengembangan sistem, requirement penting karena tahap selanjutnya tidak dapat dibuat sesuai dengan keinginan sendiri. Di tahap selanjutnya adalah analysis, pada tahap ini dilakukan untuk menggali lebih dalam dari hasil Requirement Gathering [9] dibutuhkan oleh Puskesmas bersangkutan. Development, Tahap Development merupakan tahap pengembangan program dengan menerapkan kode yang sesuai dengan rancangan UML dan rancangan user interface yang telah di buat pada tahap Design. Deployment.Tahap terakhir yaitu proses deployment, tahap ini merupakan tahap penyebaran aplikasi. Penulis melakukan penyebaran aplikasi dengan melakukan instalasi pada server Puskesmas Sakra, di karenakan hasil akhir berupa sebuah web app yang bersifat privat artinya hanya pihak puskesmas dan pasien yang berkunjung ke puskesmas yang dapat mengakses website tersebut[9]. 


\section{Hasil dan Pembahasan}

\subsection{Implementasi}

\subsubsection{Implementasi Rangkaian}

Adapun hasil implementasi rangkaian berdasarkan skematik yang di buat pada tahap desain berjalan sesuai dengan keinginan, alat mampu membaca e-KTP dan mengirimkan data ke sistem informasi. Hasil implementasi rangkaian dapat dilihat pada Gambar 1. Hasil Implementasi Rangkaian

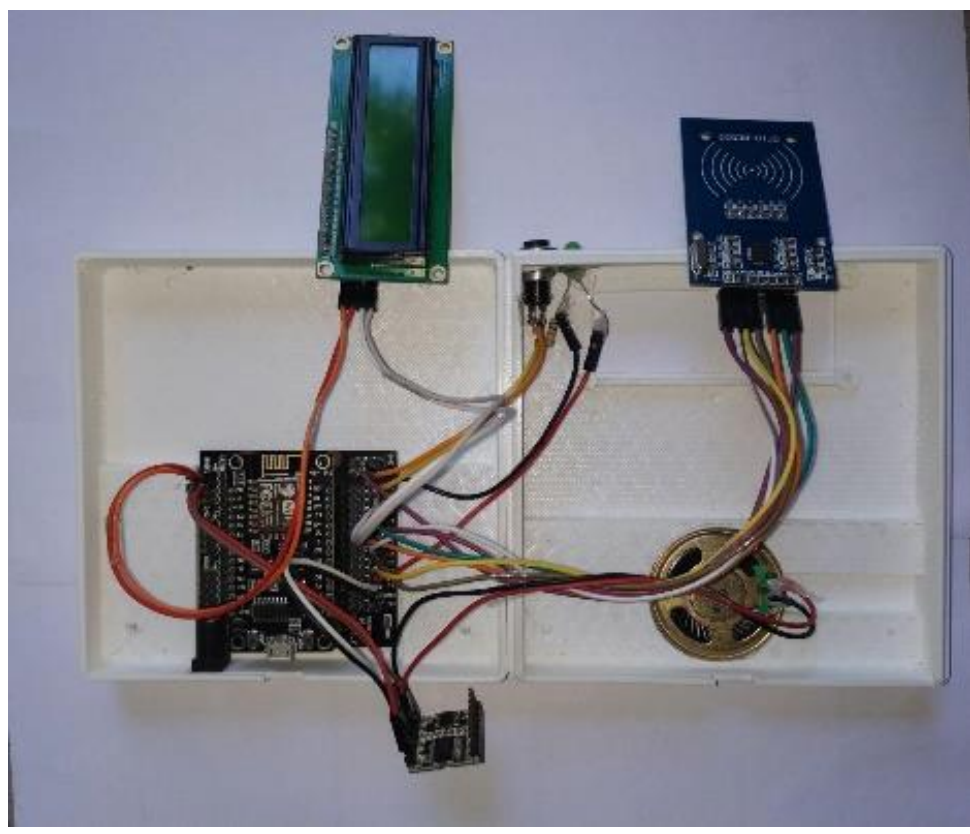

Gambar 1 Hasil implementasi rangkaian.

\subsubsection{Implementasi User Interface}

\section{A. Halaman Utama}

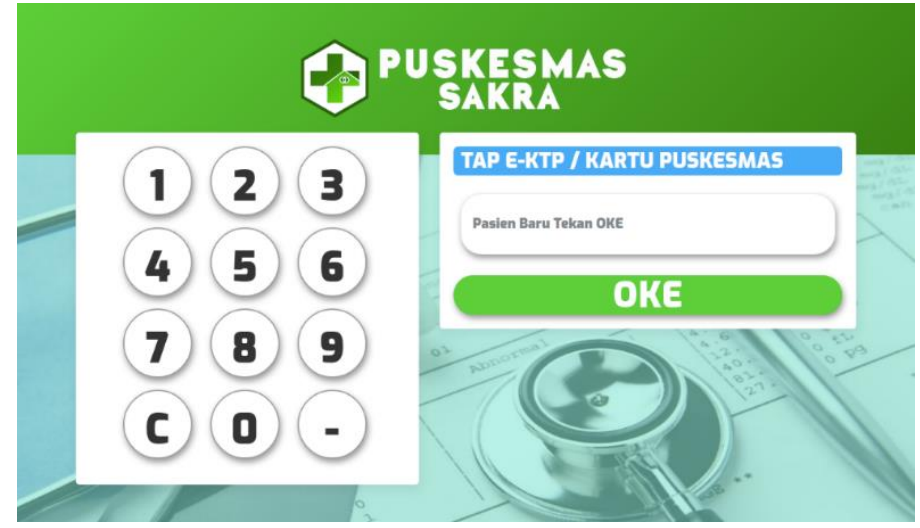

Gambar 2 Implementasi halaman utama. 


\section{B. Halaman Pemilihan Antrean}

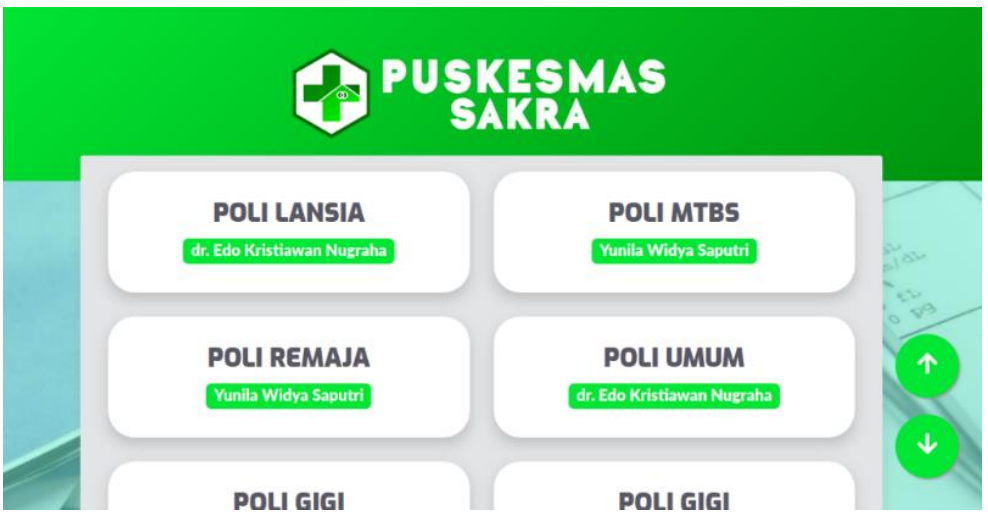

Gambar 3. Implementasi halaman pemilihan antrean

\section{Halaman Informasi Nomor Antrean}

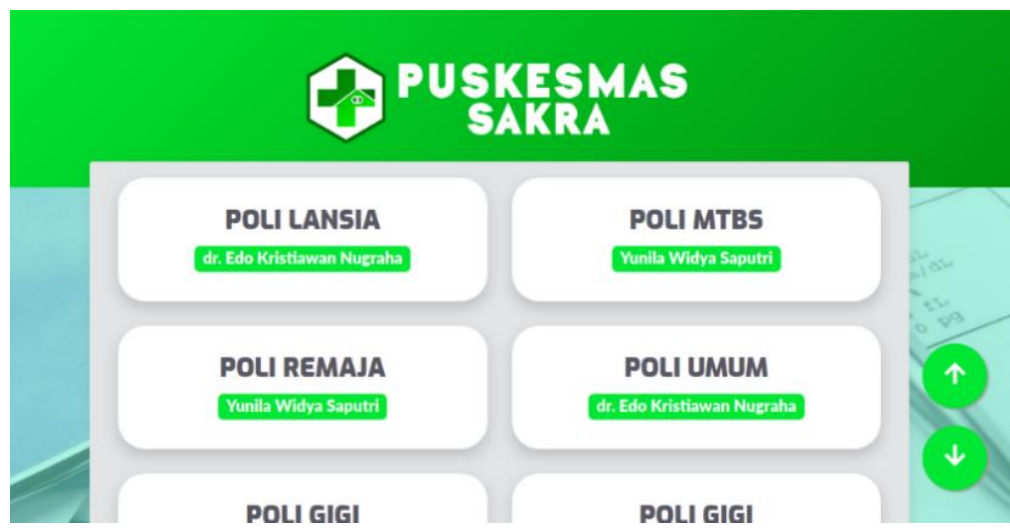

Gambar 4 Implementasi halaman informasi nomor antrean.

\section{Halaman Login}

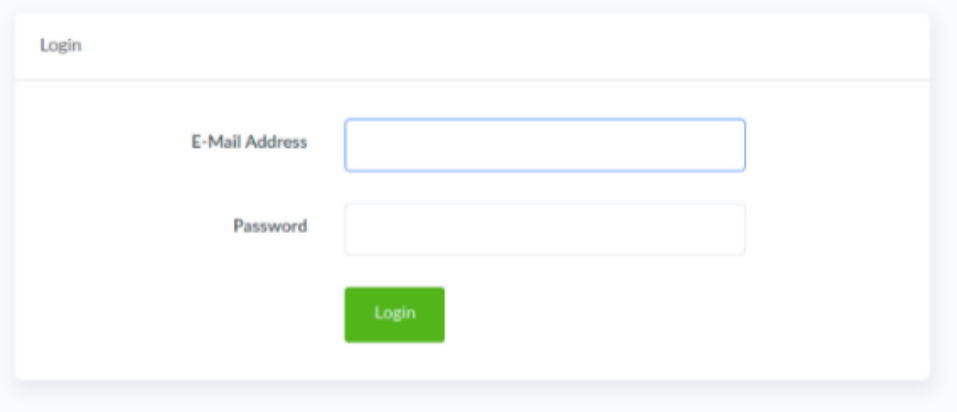

Gambar 5 Implementasi halaman login. 


\section{E. Halaman Dashboard Statistik}

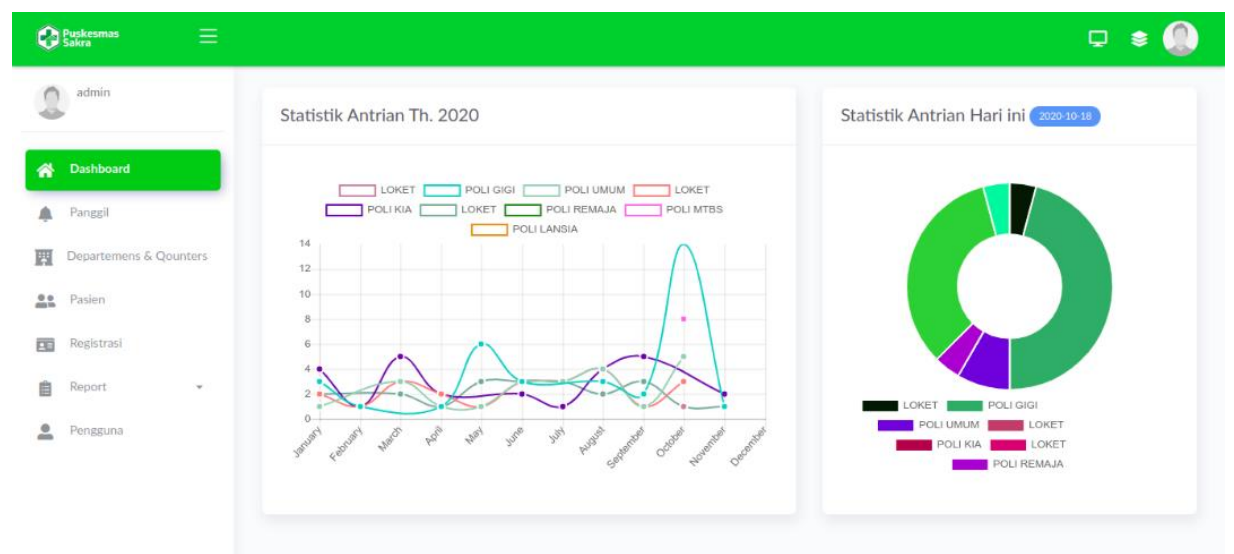

Gambar 6 Implementasi halaman dashboard statistik

\section{F. Halaman Dashboard Registrasi Kunjungan}

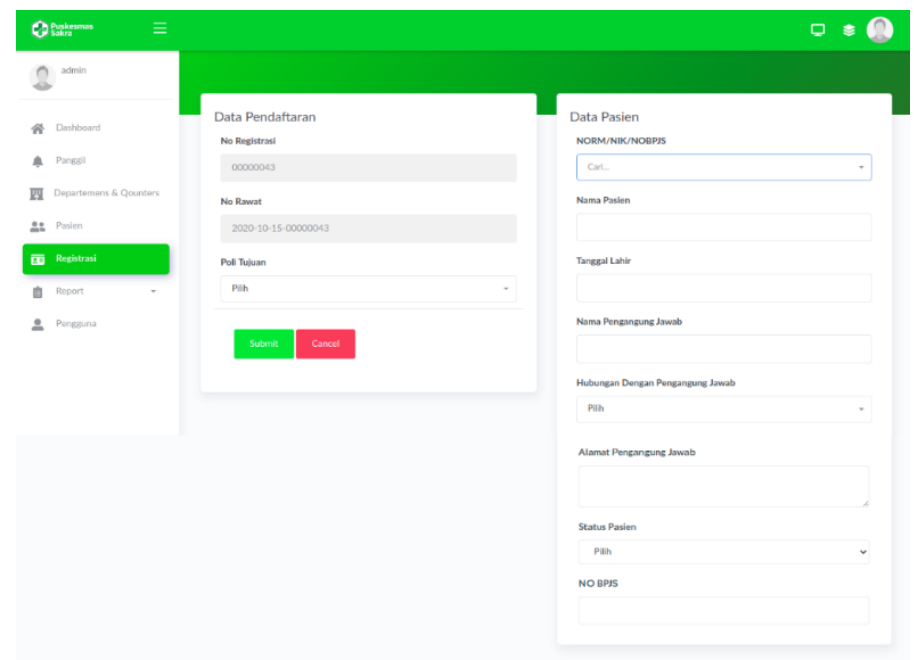

Gambar 7 Implementasi halaman dashboard registrasi kunjungan.

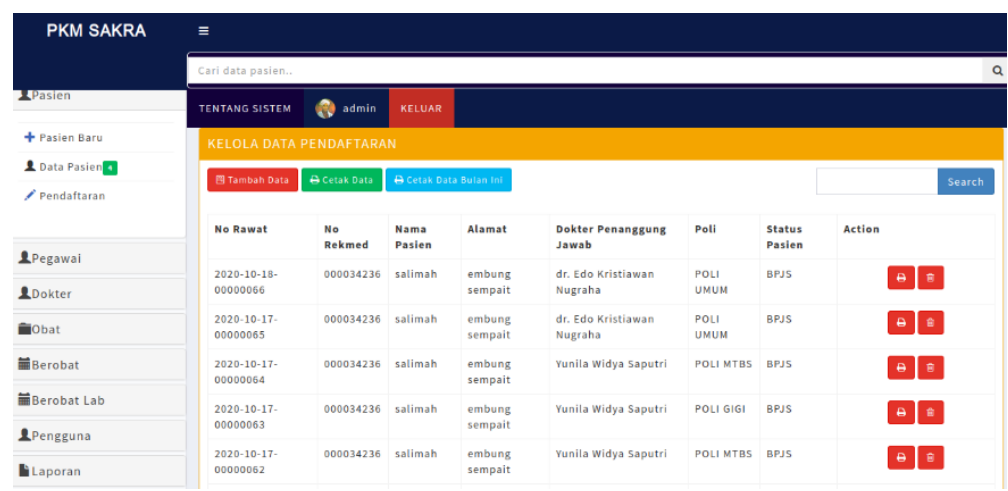

Gambar 8 Sistem rekam medis puskesmas sakra data kunjungan 


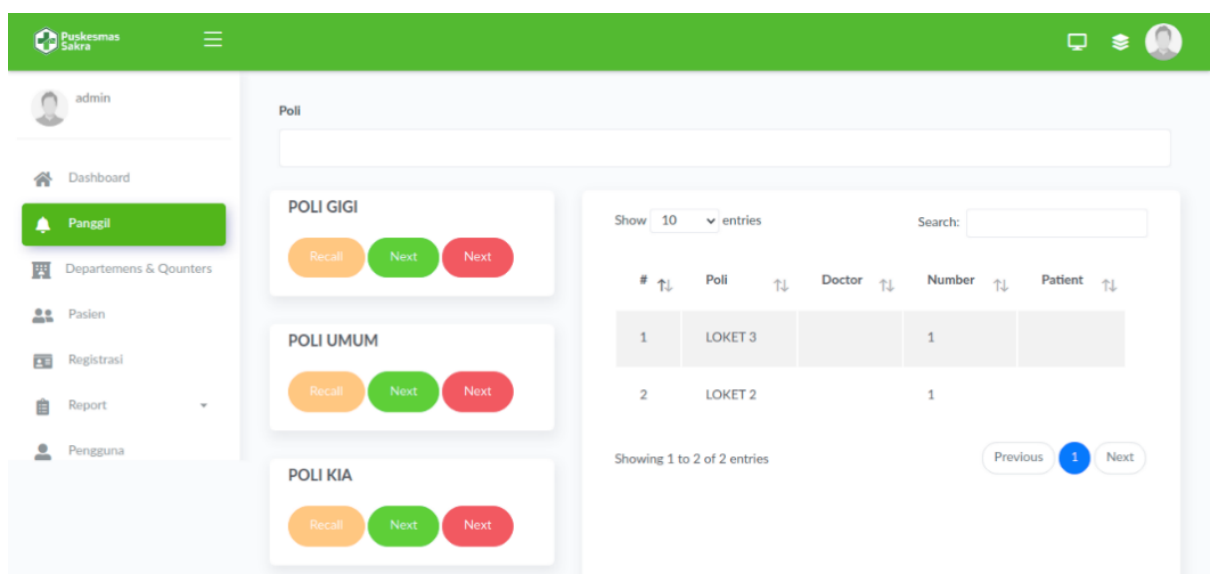

Gambar 9 Implementasi halaman dashboard panggil antrean (admin).

\section{H. Halaman Dashboard Departemen dan Konter}

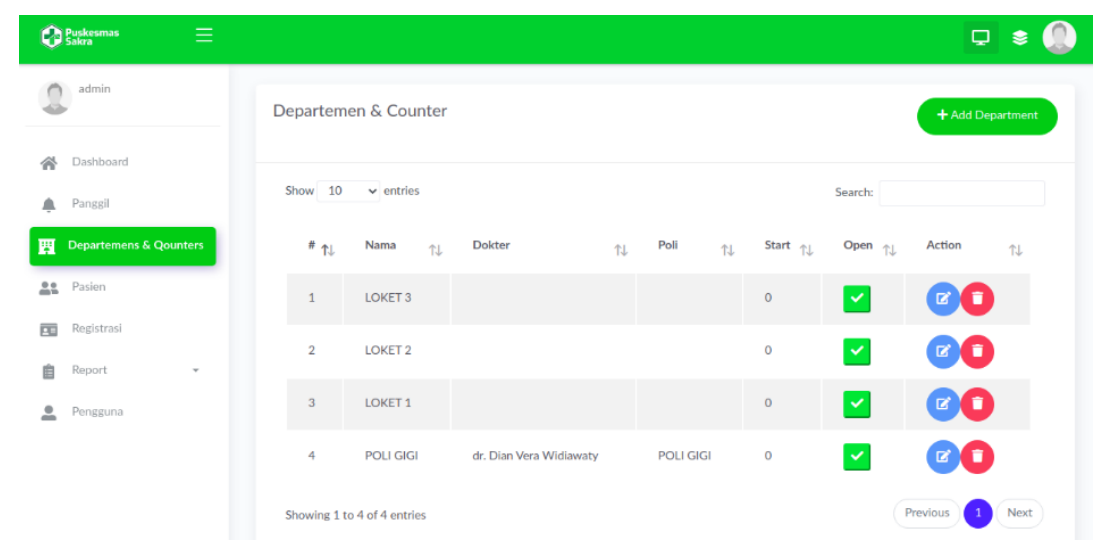

Gambar 10 Implementasi halaman dashboard departemen dan konter.

\subsection{Hasil Uji Coba}

Pengujian perangkat lunak dari segi spesifikasi fungsional tanpa menguji desain dan kode program untuk mengetahui apakah fungsi, masukan dan keluaran dari perangkat lunak sesuai dengan spesifikasi yang dibutuhkan. Metode Blackbox Testing merupakan salah satu metode yang mudah digunakan karena hanya memerlukan batas bawah dan batas atas dari data yang di harapkan, Estimasi banyaknya data uji dapat dihitung melalui banyaknya field data entri yang akan diuji, aturan entri yang harus dipenuhi serta kasus batas atas dan batas bawah yang memenuhi. Dan dengan metode ini dapat diketahui jika fungsionalitas masih dapat menerima masukan data yang tidak diharapkan maka menyebabkan data yang disimpan kurang valid [10].

\subsubsection{Alpha Test}

Tabel 1 Hasil pengujian halaman utama

\begin{tabular}{|c|c|c|c|}
\hline No. & Skenario Pengujian & Test Case & Hasil yang Diharapkan \\
\hline 1 & $\begin{array}{l}\text { Mengosongkan form } \\
\text { kemudian submit. }\end{array}$ & No. RM (kosong) & $\begin{array}{l}\text { Cetak nomor antrean loket dan Valid } \\
\text { tampilkan informasi no. } \\
\text { antrean di layar display. }\end{array}$ \\
\hline
\end{tabular}

https://journal.universitasbumigora.ac.id/index.php/bite

ISSN: 2685-4066 
2 Mengisi form dengan No. No. RM: 123 rekam medis yang tidak terdaftar kemudian submit.

3 Mengisi form No. rekam medis dengan No. rekam medis yang terdaftar

4 Tap e-KTP pada alat e-KTP (terdaftar)

5 Tap e-KTP pada alat
No. RM: 2323 e-KTP (tidak terdaftar)
Sistem akan Menampilkan

Valid notifikasi di bawah pesan eror "Maaf No. Rekam Medis Tidak Terdaftar".

Sistem akan mengalihkan ke Valid halaman pemilihan antrean

Sistem akan mengalihkan ke Valid halaman pemilihan antrean halaman pemilihan antrean Halaman tidak akan di alihkan Valid

\subsubsection{Beta Test}

\section{A. Hasil Pengujian Staff}

Tabel 2. Hasil pengisian kuesioner oleh staf Puskesmas

\begin{tabular}{|c|c|c|c|c|c|c|}
\hline \multirow{2}{*}{ No. } & \multirow{2}{*}{ Pertanyaan } & \multicolumn{5}{|c|}{ SKOR } \\
\hline & & SS & S & $\mathrm{CS}$ & TS & STS \\
\hline 1 & $\begin{array}{l}\text { Aplikasi sistem informasi antrean rekam medis } \\
\text { menggunakan e-KTP yang di buat mudah digunakan } \\
\text { tanpa mengalami kesulitan? }\end{array}$ & 0 & 8 & 0 & 0 & 0 \\
\hline 2 & $\begin{array}{l}\text { Apakah sistem yang di buat dapat menghemat waktu } \\
\text { antrean serta membantu Puskesmas dalam manajemen } \\
\text { antrean? }\end{array}$ & 1 & 6 & 1 & 0 & 0 \\
\hline 3 & $\begin{array}{l}\text { Aplikasi sistem informasi antrean menggunakan e- } \\
\text { KTP mudah di pelajari dan mudah diingat? }\end{array}$ & 0 & 8 & 0 & 0 & 0 \\
\hline 4 & $\begin{array}{l}\text { Aplikasi sistem informasi antrean menggunakan e- } \\
\text { KTP sudah mampu menampilkan seluruh interface } \\
\text { (tampilan) aplikasi tanpa ada kendala eror? }\end{array}$ & 0 & 5 & 3 & 0 & 0 \\
\hline 5 & $\begin{array}{l}\text { Aplikasi sistem informasi antrean sudah memberikan } \\
\text { kepuasan kepada pengguna? }\end{array}$ & 0 & 5 & 3 & 0 & 0 \\
\hline \multicolumn{2}{|c|}{ Jumlah } & 1 & 32 & 7 & 0 & 0 \\
\hline \multicolumn{2}{|c|}{ Jumlah Skor } & 5 & 128 & 21 & 0 & 0 \\
\hline \multicolumn{2}{|c|}{$\sum$ Skor } & \multicolumn{5}{|l|}{154} \\
\hline \multicolumn{2}{|c|}{ Presentasse } & \multicolumn{5}{|l|}{$77 \%$} \\
\hline
\end{tabular}

Jumlah skor observasi adalah jumlah dari skor masing-masing butir pernyataan hasil observasi yang dikalikan bobot skor menurut skala Likert. Skor maksimal adalah skor maksimal pada skala likert yang dikalikan dengan jumlah butir soal, sehingga $5 \times 5=25$. Jumlah Skor yang diharapkan adalah skor maksimal yang dikalikan dengan jumlah responden, sehingga $8 \times 25=$ 200. Perhitungan presentase kelayakan dari data ahli rekayasa perangkat lunak Tabel 2. Hasil pengisian kuesioner oleh staf Puskesmas menggunakan rumus sebagai berikut:

a. Jumlah Skor semuanya

$$
\begin{aligned}
& \sum \text { Skor }_{\text {observasi }}=(\text { jumlah } x \text { skorSS })+(\text { jumlah } x \text { skor } S)+(\text { jumlah } x \text { skorCS }) \\
& +(\text { jumlah } x \text { skorTS })+(\text { jumlah } x \text { skorSTS }) \\
& \sum \text { Skor }_{\text {observasi }}=(1 \times 5)+(32 \times 4)+(21 \times 3)+(0 \times 2)+(0 \times 1) \\
& \sum \text { Skor }_{\text {observasi }}=154
\end{aligned}
$$


b. Presentase kelayakan Staf Puskesmas

$$
\begin{gathered}
\text { presentase kelayakan }=\frac{\text { skorObservasi }}{\text { skoryangdiharapkan }} \times 100 \% \\
\text { presentase kelayakan }=\frac{154}{200} \times 100 \% \\
\text { presentase kelayakan }=77 \%
\end{gathered}
$$

c. Menentukan Interval Kelayakan

$$
\begin{gathered}
I=100 / \text { Jumlah Skor (Likert) } \\
I=100 / 5=20 \\
I=20
\end{gathered}
$$

d. Berikut kriteria interpretasi skornya berdasarkan interval

$$
\begin{aligned}
& \text { Angka } 0 \%-19,99 \%=\text { Sangat }(\text { tidak setuju/buruk/kurang sekali }) \\
& \text { Angka } 20 \%-39,99 \%=\text { Tidak setuju } / \text { Kurang baik }) \\
& \text { Angka } 40 \%-59,99 \%=\text { Cukup } / \text { Netral } \\
& \text { Angka } 60 \%-79,99 \%=(\text { Setuju/Baik/suka }) \\
& \text { Angka } 80 \%-100 \%=\text { Sangat }(\text { setuju/Baik/Suka })
\end{aligned}
$$

\begin{tabular}{|c|c|c|c|c|c|c|}
\hline \multirow{2}{*}{ No. } & \multirow{2}{*}{ Pertanyaan } & \multicolumn{5}{|c|}{ SKOR } \\
\hline & & SS & $\mathrm{S}$ & CS & TS & STS \\
\hline 1 & $\begin{array}{l}\text { Apakah tampilan aplikasi dan alat mudah } \\
\text { digunakan? }\end{array}$ & 34 & 35 & 10 & 0 & 1 \\
\hline & $\begin{array}{l}\text { Dengan menggunakan Sistem informasi } \\
\text { Pusat layanan Kesehatan Masyarakat }\end{array}$ & & & & & \\
\hline 2 & $\begin{array}{l}\text { Menggunakan sensor RFID pada E-KTP } \\
\text { dapat membantu dalam mendaftar untuk } \\
\text { periksa rawat jalan? }\end{array}$ & 44 & 24 & 10 & 1 & 1 \\
\hline 3 & $\begin{array}{l}\text { Aplikasi sistem informasi antrean } \\
\text { menggunakan e-KTP mudah di pelajari dan } \\
\text { mudah diingat? }\end{array}$ & 38 & 33 & 6 & 2 & 1 \\
\hline 4 & $\begin{array}{l}\text { Aplikasi sistem informasi antrean } \\
\text { menggunakan e-KTP sudah mampu } \\
\text { menampilkan seluruh interface (tampilan) } \\
\text { aplikasi tanpa ada kendala eror? (tampilan) } \\
\text { aplikasi tanpa ada kendala eror? }\end{array}$ & 31 & 26 & 18 & 4 & 1 \\
\hline 5 & $\begin{array}{l}\text { Aplikasi sistem informasi antrean sudah } \\
\text { memberikan kepuasan kepada pengguna? }\end{array}$ & 33 & 28 & 16 & 2 & 1 \\
\hline & Jumlah & 180 & 146 & 60 & 9 & 5 \\
\hline & Jumlah Skor & 900 & 584 & 180 & 18 & 5 \\
\hline & $\sum$ Skor & & & 1687 & & \\
\hline & Presentasse & & & 84.35 & & \\
\hline
\end{tabular}

Karena nilai Indeks yang dapatkan dari perhitungan adalah 80,08\%, maka dapat disimpulkan bahwa dari 8 responden Rancang Bangun Sistem informasi e-KTP menggunkan sensor RFID pada e-KTP dapat di simpulkan "BAIK".

\section{B. Hasil Pengujian Pasien}

Tabel 3. Hasil pengisian kuesioner oleh pasien.

Jumlah skor observasi adalah jumlah dari skor masing-masing butir pernyataan hasil observasi yang dikalikan bobot skor menurut skala Likert. Skor maksimal adalah skor maksimal 
pada skala likert yang dikalikan dengan jumlah butir soal, sehingga 5 x $5=25$. Jumlah Skor yang diharapkan adalah skor maksimal yang dikalikan dengan jumlah responden, sehingga $80 \times 25=$ 2000. Perhitungan presentase kelayakan dari pasien atau masyarakat umum pada table Tabel 3. Hasil pengisian kuesioner oleh pasien menggunakan rumus sebagai berikut:

a. Jumlah Skor semuanya

$$
\begin{gathered}
\sum \begin{array}{c}
\text { Skor }_{\text {observasi }}= \\
\sum \text { Skor }_{\text {observasi }}=(\text { jumlah } \times \text { skorSS })+(\text { jumlah } \times \text { skorS })+(\text { jumlah } \times \text { skorCS }) \\
+(\text { jumlah } \times \text { skorTS })+(\text { jumlah } \times \text { skorSTS })
\end{array} \\
\qquad \text { Skor }{ }_{\text {observasi }}=1687
\end{gathered}
$$

b. Presentase kelayakan pasien adalah sebagai berikut :

$$
\begin{gathered}
\text { presentase kelayakan }=\frac{\text { skorObservasi }}{\text { skoryangdiharapkan }} \times 100 \% \\
\text { presentase kelayakan }=\frac{1687}{2000} \times 100 \% \\
\text { presentase kelayakan }=84,35 \%
\end{gathered}
$$

c. Menentukan Interval Kelayakan

$$
\begin{gathered}
\mathrm{I}=100 / \text { Jumlah Skor (Likert) } \\
\mathrm{I}=100 / 5=20 \\
\mathrm{I}=20
\end{gathered}
$$

d. Berikut kriteria interpretasi skornya berdasarkan interval:

Angka 0\% - 19,99\% = Sangat (tidak setuju/buruk/kurang sekali)

Angka 20\% - 39,99\% = Tidak setuju / Kurang baik)

Angka $40 \%-59,99 \%=$ Cukup $/$ Netral

Angka $60 \%-79,99 \%=($ Setuju/Baik/suka $)$

Angka $80 \%-100 \%=$ Sangat (setuju/Baik/Suka)

Karena nilai Indeks yang dapatkan dari perhitungan adalah 84,35\%, maka Rancang Bangun Sistem informasi e-KTP menggunkan sensor RFID pada e-KTP "SANGAT BAIK".

e. Evaluasi

Sistem Informasi Pusat Layanan Kesehatan Masyarakat Menggunakan Sensor RFID pada E-KTP dapat dibuat dan dioperasikan dengan mikrokontroler ESP8266 sebagai pusat kendali rangkaian dan di program menggunakan bahasa pemrograman PHP dengan kerangka kerja LARAVEL. dengan bantuan fitur Multi Database yang memudahkan dalam sikonisasikan sistem Rekam Medis yang belum memiliki webservice,

Alat mampu membaca ID kartu dengan jarak toleransi $4 \mathrm{~cm}$ pada kartu RFID konvensional dan pada e-KTP dengan jarak $3 \mathrm{~cm}$ tanpa halangan, sedangkan pada media penghalang plastik dengan ketebalan $2 \mathrm{~mm}$ alat mampu membaca kartu RFID konvensional dengan jarak toleransi 4 $\mathrm{cm}$ dan e-KTP $2.5 \mathrm{~cm}$.

Sistem yang dirancang berjalan sesuai rancangan penulis setelah dilakukannya tahap pengujian alpha test dan beta test dimana alfha test di lakukan pada lingkup pengebangan dengan metode blackbox, sedangkan pada tahap beta test di lakukan di lingkup pengguna dengan menggunakan metode kusioner, dari hasil pengujian tersebut sistem informasi yang di bangun dapat di katakana layak untuk di implementasikan. 


\section{Kesimpulan}

Adapun kesimpulan yang dapat di ambil dari hasil penelitian yaitu Sistem Informasi Pusat Layanan Kesehatan Masyarakat Menggunakan Sensor RFID pada E-KTP dapat dibuat dan dioperasikan dengan mikrokontroler ESP8266 sebagai pusat kendali rangkaian dan di program menggunakan bahasa pemrograman PHP dengan kerangka kerja LARAVEL dan Alat mampu membaca ID kartu dengan jarak toleransi $4 \mathrm{~cm}$ pada kartu RFID konvensional dan pada e-KTP dengan jarak $3 \mathrm{~cm}$ tanpa halangan, sedangkan pada media penghalang plastik dengan ketebalan $2 \mathrm{~mm}$ alat mampu membaca kartu RFID konvensional dengan jarak toleransi $4 \mathrm{~cm}$ dan e-KTP 2.5 $\mathrm{cm}$.

\section{Ucapan Terima Kasih}

Terima kasih disampaikan kepada Tim BITe yang telah meluangkan waktu untuk membuat template ini.

\section{Referensi}

[1] J. Heizer and B. Render, Operations Management : Manajemen Operasi. Jakarta: Salemba Empat, 2005.

[2] A. Helmi, "Study of Shopping Style as Expressions of Personal Values," Review of Integrative Business and Economics Research, vol. 5, no. 1, pp. 346-356, 2016.

[3] P. A. R. Suryadhi and N. J. Manurung, "Model Antrian Pada Pelayanan Kesehatan Di Rumah Sakit," Majalah Ilmiah Teknologi Elektro, vol. 8, no. 2, 2012, doi: 10.24843/10.24843/MITE.

[4] E. B. Setiawan and B. Kurniawan, "Perancangan Sistem Absensi Kehadiran Perkuliahan dengan Menggunakan Radio Frequency Identification ( RFId )," vol. 1, no. 2, pp. 44-49, 2015.

[5] R. Weinstein, "RFID: A technical overview and its application to the enterprise," IT Professional, vol. 7, no. 3, pp. 27-33, 2005, doi: 10.1109/MITP.2005.69.

[6] R. Susanto, A. Ananta, A. Santoso, and M. Trianto, "Sistem Absensi Berbasis Rfid," Jurnal Teknik Komputer, vol. 17, no. 9, pp. 67-74, 2017.

[7] R. E. Putera and T. R. Valentina, "Implementasi Program KTP Elektronik ( e-KTP ) di Daerah Percontohan," vol. XXVII, no. 2, pp. 193-201, 2011.

[8] A. Sucipto, R. H. Kusumodestoni, A. K. Zyen, and M. Husen, "Penerapan Aplikasi Mobile Information Karimun Island Menggunakan Ionic Framework," JTET (Jurnal Teknik Elektro Terapan), vol. 7, no. 1, pp. 1-30, 2018.

[9] J. Schmuller, Sams Teach Yourself UML in 24 Hours, (1 st ed.). Indianapolis: Sams Publishing, 1999.

[10] W. N. Cholifah, Y. Yulianingsih, and S. M. Sagita, "Pengujian Black Box Testing pada Aplikasi Action \& Strategy Berbasis Android dengan Teknologi Phonegap," STRING (Satuan Tulisan Riset dan Inovasi Teknologi), vol. 3, no. 2, p. 206, 2018, doi: 10.30998/string.v3i2.3048. 